\title{
Reaction of Winter Wheat Cultivars to Artificially Inoculated Seed-borne Pink Snow Mold
}

\author{
Norio Iriki¹), Takashi Nakajimaa ${ }^{2}$ and Akira Kawakami ${ }^{1)}$ \\ 1) National Agricultural Research Center for Hokkaido Region, 1 Hitsujigaoka, Toyohira, Sapporo, Hokkaido 062-8555, Japan \\ 2) National Agricultural Research Center for Kyusyu Okinawa Region, 2421 Suya, Nishigoshi, Kumamoto 861-1192, Japan
}

\begin{abstract}
Key Words: Microdochium nivale, Typhula ishikariensis, conidia, seed-borne disease, snow mold, winter wheat.
\end{abstract}

In the central region of Hokkaido, the northern island of Japan, which is characterized by a deep, persistent snow cover during most winters, winter wheats suffer snow mold injury caused predominantly by Microdochium nivale (Ces. ex Berl. \& Vogl.) Sumuels \& Hallet (pink snow mold), Typhula ishikariensis S. Imai (speckled snow mold), $T$. incarnata Lasch ex Fr. (gray snow mold), or Pythium spp. (pythium snow rot). Chemical control of snow molds can be effective, but fungicides must be applied as a spray to the wheat just before the onset of the permanent snow cover. The exact time of permanent snow cover is difficult to predict and the effectiveness can be eroded due to snow melt during late autumn and early winter. The most practical method of controlling snow molds is growing resistant cultivars. Evaluation of genetic resources and screening breeding lines for snow mold resistance is routinely carried out in breeding programs, and testing methods in artificially infested plots or under controlled conditions have been developed (Amano 1987, Iriki and Kuwabara 1992, Kunii 1987, Nakajima and Abe 1990). Inoculum consisting of sclerotia or cultured mycelium are frequently applied to wheat plots to simulate natural infection. For the pink snow mold pathogen, an important means of dissemination and infection is seed-borne inoculum (Nakajima and Nemoto 1987, Tronsmo et al. 2001). Nakajima and Nemoto (1987) reported different levels of resistance to the seed-borne stage of pink snow mold in wheat cultivars Nanbukomugi and Kitakamikomugi. No other reports on varietal differences in resistance to seed-borne pink snow mold have been published. We observed the reaction of wheat cultivars to artificial inoculation of pink snow mold by soaking seeds in a conidial suspension of $M$. nivale in field experiments at Sapporo which typifies conditions in the central region of Hokkaido characterized by a deep, persistent snow cover.

Communicated by J. Michael Bonman

Received November 22, 2001. Accepted February 15, 2002.

*Corresponding author (e-mail: iriki@affrc.go.jp)

\section{Inoculation with conidia}

$M$. nivale, recently isolated from naturally infected wheat plants, was cultured in a V8 agar medium (Commonwealth Mycological Institute 1983 ) at $20^{\circ} \mathrm{C}$ for two weeks in petri dishes under Black Light Blue lamp ( $24 \mathrm{~h}$ per day). The conidia were isolated by flooding the petri dishes with sterile distilled water and gently agitating the cultures with an artist's paint brush. Conidia were filtered through four layers of cheese cloth, centrifuged at $3000 \mathrm{rpm}$, re-suspended in $0.5 \%$ methyl cellulose solution, and the concentration was adjusted to $2 \times 10^{7}$ conidia per $\mathrm{ml}$ (high concentration) or $2 \times 10^{5}$ conidia per $\mathrm{ml}$ (low concentration).

Seeds of winter wheat cultivars were surface-sterilized for $3 \mathrm{~min}$ in $0.5 \%$ sodium hypochroride solution, and washed in sterile distilled water. The sterilized seeds were soaked in a conidial suspension of $M$. nivale under vacuum $\left(1.01 \times 10^{4} \mathrm{~Pa}\right)$ for 30 minutes, and dried at room temperature overnight. The seeds of control treatments were similarly treated except that they were soaked in sterile distilled water.

Disease severities among four winter wheat cultivars during three years

Inoculation of wheat cultivars with seed-borne pink snow mold using a seed-soak technique was compared to natural infection during 1996/1997, 1997/1998 and 1998/ 1999. The cultivars, PI 173438 (highly resistant to speckled snow mold), Horoshirikomugi (resistant), Chihokukomugi (medium), and Ibis (susceptible) were employed.

Cultivars were seeded in mid-September and each plot consisted of a single row of plants with $9 \mathrm{~cm}$ spacing between plants in each row, and $60 \mathrm{~cm}$ between rows. Disease severity caused by seed-borne pink snow mold, or natural infestation by snow mold fungi, was observed following spring regrowth. Individual plants were visually rated on a 0 to 5 scale as follows: $0=$ no damage; $1=$ half of the leaves dead; $2=$ all leaves dead; $3=$ less than half of shoots dead; $4=$ the majority of shoots dead; $5=$ plant dead. A split-plot design with four replications was employed in which inoculation method served as main plot and cultivar as sub-plot.

The germination levels for cultivars did not vary between the low and high concentrations of $M$. nivale conidia (data not shown). The duration of snow cover ranged between 103 and 147 days (Table 1) which was sufficient to provide conditions for adequate levels of snow mold to dis- 
Table 1. Duration of snow cover

\begin{tabular}{cccc}
\hline \hline Year & Start & End & Duration (days) \\
\hline $1996 / 1997$ & December 19 & April 2 & 104 \\
$1997 / 1998$ & December 21 & April 3 & 103 \\
$1998 / 1999$ & November 18 & April 13 & 147 \\
\hline
\end{tabular}

tinguish treatment effects.

Pink snow mold was the predominant snow mold disease in inoculated plots whereas speckled snow mold predominated in the uninoculated plots during all three years. During 1996/1997, varietal differences in disease severity were observed in plots inoculated with the higher concentration of conidia by the seed-soaking technique and in naturally infested plots with speckled snow mold (Table 2). Inoculation of seeds with M. nivale conidia increased the disease severity and the highest disease severity occurred in plots inoculated with the high concentration of conidia. During $1997 / 1998$ and 1998/1999, varietal differences in the disease severity were observed in both inoculated and uninoculated plots, however, the differences between inoculated and uninoculated plots, averaged over varieties, were not significant. During all three years, PI 173438 exhibited the lowest levels of disease severity caused by seed-borne pink snow mold followed by Horoshirikomugi. Ibis showed the highest values. This ranking was in agreement with previously published reports on varietal resistance to speckled snow mold (Iriki and Kuwabara 1992) and soil-borne pink snow mold

Table 2. Disease severity ratings in plots inoculated with seedborne pink snow mold using the seed-soak technique

\begin{tabular}{clccc}
\hline \hline \multirow{2}{*}{ Year } & \multicolumn{1}{c}{ Cultivar } & \multicolumn{3}{c}{ Inoculation of M. nivale conidia } \\
\cline { 3 - 5 } & & None ${ }^{1)}$ & $\begin{array}{c}\text { Low }^{2} \\
\text { concen- } \\
\text { tration }\end{array}$ & $\begin{array}{c}\text { High }^{2} \\
\text { concen- }^{\text {tration }}\end{array}$ \\
\hline 1996/1997 & PI 173438 & $1.02 \mathrm{a}$ & $1.45 \mathrm{a}$ & $1.75 \mathrm{a}$ \\
& Horoshirikomugi & $1.39 \mathrm{ab}$ & $2.29 \mathrm{a}$ & $2.65 \mathrm{ab}$ \\
& Chihokukomugi & $1.79 \mathrm{bc}$ & $2.72 \mathrm{a}$ & $3.68 \mathrm{~b}$ \\
& Ibis & $1.89 \mathrm{c}$ & $2.19 \mathrm{a}$ & $3.41 \mathrm{~b}$ \\
& Mean & $1.52 \mathrm{a}$ & $2.16 \mathrm{a}$ & $2.87 \mathrm{~b}$ \\
1997/1998 & PI 173438 & $0.65 \mathrm{a}$ & $0.67 \mathrm{a}$ & $0.71 \mathrm{a}$ \\
& Horoshirikomugi & $0.86 \mathrm{a}$ & $1.08 \mathrm{ab}$ & $1.19 \mathrm{ab}$ \\
& Chihokukomugi & $0.91 \mathrm{a}$ & $1.22 \mathrm{~b}$ & $1.34 \mathrm{~b}$ \\
& Ibis & $1.38 \mathrm{~b}$ & $1.40 \mathrm{~b}$ & $1.41 \mathrm{~b}$ \\
& Mean & $0.95 \mathrm{a}$ & $1.09 \mathrm{a}$ & $1.17 \mathrm{a}$ \\
1998/1999 & PI 173438 & $1.27 \mathrm{a}$ & $1.40 \mathrm{a}$ & $1.58 \mathrm{a}$ \\
& Horoshirikomugi & $1.76 \mathrm{ab}$ & $2.73 \mathrm{ab}$ & $2.43 \mathrm{~b}$ \\
& Chihokukomugi & $2.52 \mathrm{bc}$ & $3.34 \mathrm{bc}$ & $3.70 \mathrm{c}$ \\
& Ibis & $3.44 \mathrm{c}$ & $4.07 \mathrm{c}$ & $3.86 \mathrm{c}$ \\
& Mean & $2.50 \mathrm{a}$ & $2.89 \mathrm{a}$ & $2.85 \mathrm{a}$ \\
\hline
\end{tabular}

1) The predominant snow mold disease was speckled snow mold.

2) Low concentration, $2 \times 10^{5}$ conidia per $\mathrm{mL}$; high concentration, $2 \times 10^{7}$ conidia per $\mathrm{mL}$.

3) Values followed by the same letters in the same column for cultivars and the same row for means among each inoculation treatment were not significantly different according to Duncan's Multiple Range test $(\mathrm{P}=0.05)$.
(Amano 1987, Nakajima and Abe 1990).

\section{Disease severities among 31 winter wheat cultivars during 1998/1999}

During 1998/1999, the disease severities among 31 cultivars caused by artificially inoculated seed-borne pink snow mold using the seed-soak technique, and by naturally occurred speckled snow mold, were compared. A high concentration of conidia and a randomized complete block design with four replications were employed. Disease severities observed among the 31 winter wheat cultivars were highly correlated ( $\mathrm{r}=0.90, \mathrm{P}<0.01)$ (Fig. 1). The cultivars PI 173438, Münstertaler, Niederndorferberg, and Haunsberg, reported to be resistant to both speckled and soil-borne pink snow mold (Kuwabara et al. 1996), exhibited the lowest levels of disease severity to seed-borne pink snow mold.

In conclusion, varietal differences in the resistance to seed-borne pink snow mold were confirmed. In addition, speckled snow mold resistance, which is positively correlated with resistances to gray snow mold, soil-borne pink snow mold and possibly to pythium snow rot (Amano 1987, Bruehl 1967, Lipps and Bruehl 1980), was confirmed to be positively correlated with the resistance to seed-borne pink snow mold.

\section{Acknowledgement}

The authors thank Dr. D.A. Gaudet, Lethbridge Research Centre, for his helpful advise in preparing the manuscript.

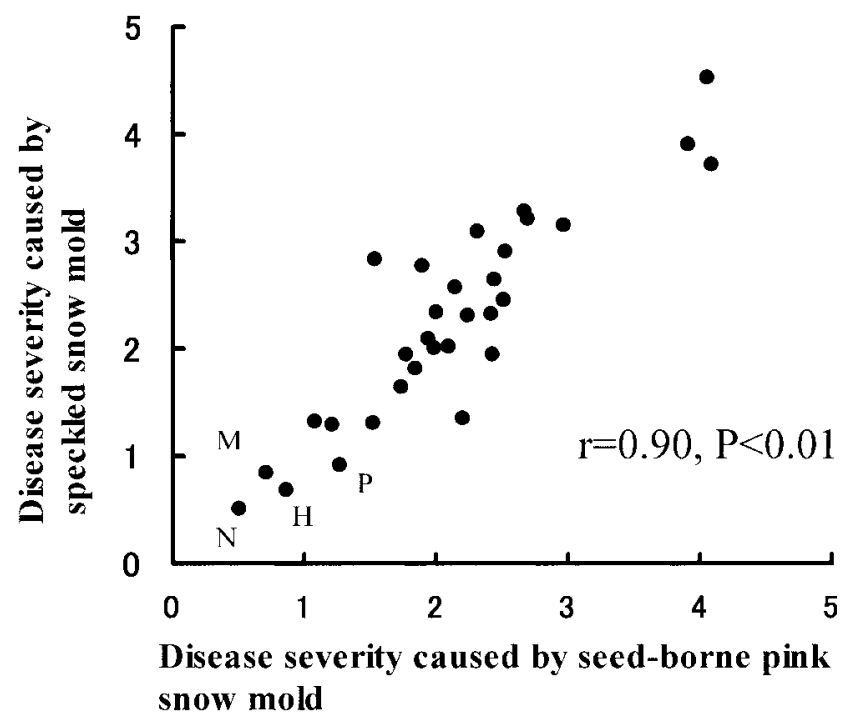

Fig. 1. Relationship between disease severity of wheat cultivars caused by artificially inoculated seed-borne pink snow mold and naturally infected speckled snow mold.

P, PI 173438; M, Münstertaler; H, Haunsberg; N, Niederndorferberg. 


\section{Literature Cited}

Amano,Y. (1987) Studies on methods of breeding wheat for winter hardiness. Rep. Hokkaido Prefec. Agric. Exp. Stn. 64: 1-79 (in Japanese with English summary).

Bruehl,G.W. (1967) Lack of significant pathogenic specialization within Fusarium nivale, Typhula idahoensis, and T. incarnata and correlation of resistance in winter wheat to these fungi. Plant Dis. Rep. 51: 810-814.

Commonwealth Mycological Institute (1983) Plant pathologist's pocketbook, second edition. Commonwealth Agricultural Bureaux, London. $439 \mathrm{p}$

Iriki,N. and T.Kuwabara (1992) Field resistance of winter wheat varieties to Typhula ishikariensis biotype A, B, or C in artificially infested plots. Jpn. J. Breed. 42: 843-852 (in Japanese with English summary).

Kunii,T. (1987) Studies on winter killing of winter wheat in Kamikawa district. VII. Testing varietal differences of resistance to Typhula incarnata in artificially infested plots. Hokuno 54 (3):
28-39 (in Japanese).

Kuwabara,T., J.Abe, N.Iriki, T.Tsuchiya and T.Nakajima (1996) New genetic resources for resistance to snow molds in wheat (Triticum aestivum L.). Breed. Sci. 46: 409-411 (in Japanese).

Lipps,P.E. and G.W.Bruehl (1980) Reaction of winter wheat to Pythium snow rot. Plant Disease 64: 555-558.

Nakajima,T. and J.Abe (1990) A method for assessing resistance to the snow molds Typhula incarnata and Microdochium nivale in winter wheat incubated at the optimum growth temperature ranges of the fungi. Can. J. Bot. 68: 343-346.

Nakajima,T. and M.Nemoto (1987) Relationship between wheat scab and pink snow mold. Tohoku Agric. Res. 40: 119-120 (in Japanese).

Tronsmo,A.M., T.Hsiang, H.Okuyama and T.Nakajima (2001) Low temperature diseases caused by Microdochium nivale. In "Low temperature plant microbe interactions under snow" Iriki,N., D.A.Gaudet, A.M.Tronsmo, N.Matsumoto, M.Yoshida and A. Nishimune (eds.), Hokkaido Natl. Agric. Exp. Stn., Sapporo. p. 75-86. 